\title{
KEPUTUSAN PEMBELIAN DAN SIKAP KONSUMEN ROTI MEREK SARI ROTI (Studi Kasus pada Mahasiswa S1 Institut Pertanian Bogor)
}

\author{
Risa Martha Muliasari'1), dan Dwi Rachmina²) \\ ${ }^{1,2)}$ Departemen Agribisnis, Fakultas Ekonomi dan Manajemen, Institut Pertanian Bogor \\ ${ }^{1)}$ risamarthamuliasari@yahoo.com
}

\begin{abstract}
Sari Roti is a bakery product produced by Nippon Indosari Corpindo. The purposes of this research are to describe characteristics of consumers, analyze the process of consumer's desicion making and also to analyse the consumer attitudes towards Sari Roti's product attributes. Methods used include Descriptive Analysis and Fishbein Multi-Attitude Model involving one hundred respondents of BAU's undergraduate students. The samples are purposively selected on the basis that most of students prefer to eat Sari Roti in the morning or during the break time. Most of the consumers of Sari Roti are women, 18 to 22 years old, where their monthly allowance (IDR 500,000 to 999,999) comes from parents. Descriptive Analysis shows that in general, five stages of purchasing decision were passed. Overall, result of consumers's attitude towards Sari Roti brand is positive based on Fishbein Multi-attribute Attitude Model. Clarity of expiry date of the product become the most important attribute of consideration. However, attribute of price should be taken into consideration, as it obtained smallest evaluation score and will determine how many purchases are made.
\end{abstract}

Keyword(s): bread purchasing decision, Fishbein

\begin{abstract}
ABSTRAK
Sari Roti adalah produk roti diproduksi oleh PT Nippon Indosari Corpindo. Tujuan dari penelitian ini adalah menggambarkan karakteristik konsumen, menganalisis proses pengambilan keputusan konsumen dan menganalisis sikap konsumen terhadap atribut produk roti merek Sari Roti. Metode yang digunakan meliputi Analisis Deskriptif dan Model Sikap Multiatribut Fishbein dengan melibatkan seratus sampel mahasiswa S1 Institut Pertanian Bogor. Penentuan sampel dipilih secara sengaja dengan pertimbangan bahwa kebanyakan dari mahasiswa suka mengonsumsi roti merek Sari Roti di saat pagi hari atau ketika jam istirahat. Karakteristik konsumen roti merek Sari Roti yaitu sebagian besar perempuan, berusia sekitar 18 hingga 22 tahun dan sumber keuangan setiap bulan masih banyak yang berasal dari orang tua yang berkisar antara 500.000 rupiah sampai dengan 999.999 rupiah. Analisis Deskriptif menunjukkan bahwa konsumen melalui lima tahapan pembelian. Berdasarkan Model Sikap Multiatribut Fishbein, secara keseluruhan sikap konsumen terhadap roti merek Sari Roti adalah positif. Konsumen menjadikan kejelasan kadaluarsa sebagai atribut pertimbangan paling penting. Namun atribut harga perlu diperhatikan, karena memperoleh skor evaluasi terkecil dan akan menentukan seberapa banyak pembelian yang dilakukan.
\end{abstract}

Kata Kunci: keputusan pembelian roti, Fishbein 


\section{PENDAHULUAN}

Pola konsumsi pangan masyarakat Indonesia semakin mengalami perubahan. Hal ini dapat dilihat dari perkembangan produk siap saji sebagai makanan praktis sehari-hari. Berdasarkan fenomena lingkungan sekitar, salah satu makanan favorit pengganti nasi adalah mie dan roti. Namun, mie masih harus dimasak terlebih dahulu meskipun memerlukan waktu yang relatif lebih singkat untuk dapat disajikan dibandingkan nasi. Berbeda dengan roti, makanan tersebut sengaja dibuat agar orang dengan sedikit waktu tidak perlu berlama-lama untuk menunggu sarapan, makan siang ataupun makan malam. Roti juga berpotensi menjadi makanan keseharian mahasiswa karena kuliah dan aktivitas mereka padat sehingga tidak memungkinkan menyantap makanan di warung atau memasak sendiri. Keadaan inilah pada akhirnya menjadi gaya hidup anak muda jaman sekarang.

Menurut hasil uji beda untuk konsumsi pangan mahasiswa (konsumsi beras, protein nabati, protein hewani dan karbohidrat non-beras) tidak ada perbedaan konsumsi ketika sebelum dan sesudah kenaikan BBM. Hal ini disebabkan oleh alasan perlunya energi dari konsumsi pangan tersebut dalam melakukan aktivitas padat mereka (Siti, 2006). Menteri Koordinator Bidang Perekonomian Hatta Rajasa pernah mengungkapkan bahwa selama ini anak muda dan masyarakat kelas menengah suka makan roti sedangkan masyarakat kelas bawah suka makan mie, sehingga untuk dapat menghasilkan kedua produk tersebut, Indonesia membutuhkan kontinuitas pasokan gandum. ${ }^{3}$

Awalnya roti merupakan makanan orang Belanda pada zaman penjajahan, namun kini sudah mampu menjadi makanan pokok kedua karena karakteristiknya hampir sama dengan nasi. Pertama, roti mengandung karbohidrat yang tinggi. Oleh karena itu, orang akan memperoleh kalori sebagai sumber energi yang cukup dengan mengonsumsi roti. Kedua, roti bergizi tinggi. Kandungan gizi dalam roti melengkapi kebutuhan nutrisi orang yang mengonsumsinya. Kandungan gizi produk olahan tepung tersebut lebih unggul dibandingkan dengan nasi dan mie. Bahkan selain kaya serat, beberapa jenis roti mengandung omega-3 yang berfungsi sebagai penangkal berbagai penyakit degeneratif. Berikutnya, roti dapat disajikan dengan beragam rasa dan penyajian, hal ini karena teknologi pembuatan roti pada saat ini memungkinkan penambahan rasa dan penyajian yang beragam sehingga roti dapat dinikmati oleh masyarakat yang memiliki beragam selera pula. Selain memiliki karakteristik sebagai makanan pokok, roti juga bersifat lebih praktis untuk dikonsumsi dibandingkan bahan makanan lain. Sifat tersebut mengarahkan roti untuk memenuhi kebutuhan gaya hidup masyarakat yang semakin modern. ${ }^{4}$

\footnotetext{
${ }^{3}$ Editor Kabarbisnis. 2013. Konsumsi mi instan dan roti meningkat, impor gandum RI Rp $55 \mathrm{~T}$. http://kabarbisnis.com/read/2843431. Diakses 16 Nopember 2013.

${ }^{4}$ Joko M. 2011. Tren konsumsi roti sebagai makanan pokok masyarakat Indonesia. http://dninisbakery.webs.com/apps/blog/show/5980696-tren-konsumsi-roti-sebagai-makanan-pokokmasyarakat-indonesia. Diakses 6 Mei 2014.
} 
Meningkatnya kebutuhan masyarakat akan produk makanan yang sehat dan praktis merupakan sebuah peluang bagi produsen roti. Peluang ini juga didorong oleh pertumbuhan ekonomi masyarakat kelas menengah di Indonesia. Sebagai produsen roti nasional, PT Nippon Indosari Corpindo terus mengembangkan sistem pemasaran dan memperluas area jangkauan distribusi. Berbagai kegiatan promosi dilakukan secara berkesinambungan untuk meningkatkan penjualan produk dan semakin mendekatkan roti merek Sari Roti di hati dan pikiran masyarakat.

Pengambilan keputusan menjadi sangat penting bagi individu karena membantu untuk mengidentifikasi dan memilih alternatif berdasarkan prinsipprinsip dan preferensi. Hal ini memungkinkan fungsi bisnis berjalan lancar tanpa rintangan, apabila keputusan individu sebagai konsumen sesuai dengan ekspektasi produsen. ${ }^{5}$

Konsumen roti mencakup hampir semua kalangan termasuk mahasiswa. Kewajiban kuliah, praktikum, kerja kelompok atau aktivitas kampus lainnya seringkali membuat para mahasiswa kurang memperhatikan apa yang mereka makan sehari-hari. Charles (2013) menyimpulkan bahwa globalisasi meningkatkan konsumsi makanan instan diantara mahasiswa. Empat faktor utama dari kondisi universitas yang memengaruhi pola makan mahasiswa yaitu waktu makan siang yang terbatas, pertemuan atau event tertentu di kampus, jadwal kuliah yang ketat dan jam kuliah kosong. Ketersediaan roti merek Sari Roti di minimarket dan warung kecil sekitar kampus Institut Pertanian Bogor mengarahkan akses mahasiswa terhadap produk tersebut menjadi sangat mudah. Akibat terlalu dominan dan sering dilihat, roti merek Sari Roti sudah mampu mendapatkan posisi kuat di ingatan mahasiswa daripada roti merek lainnya. Ketika beban tugas mereka semakin mengurangi waktu untuk sarapan, makan siang atau makan malam, maka alternatif lain yang dimungkinkan adalah pembelian roti merek Sari Roti akan lebih tinggi. Namun hipotesis tersebut belum pasti kebenarannya. Warung dan minimarket tidak hanya menjual roti merek Sari Roti saja, tetapi tersedia juga beragam roti UMKM dengan harga lebih murah.

Setiap konsumen melakukan berbagai macam keputusan tentang pencarian, pembelian, penggunaan beragam produk dan merek setiap periode tertentu. Konsumen melakukan keputusan setiap hari atau setiap periode tanpa menyadari bahwa mereka telah mengambil keputusan. Disiplin perilaku konsumen berusaha mempelajari bagaimana konsumen mengambil keputusan dan memahami faktor-faktor apa saja yang memengaruhi dan yang terlibat dalam pengambilan keputusan tersebut (Sumarwan, 2003).

Berdasarkan latar belakang dan perumusan masalah yang telah di-

\footnotetext{
${ }^{5}$ Editor Ciputranews. 2013. 10 Keinginan konsumen yang harus diperhatikan pengusaha. http://www.ciputraentrepreneurship.com/pelayanan-konsumen/10-keinginan-konsumen-yang-harusdiperhatikan-pengusaha. Diakses 16 Nopember 2013.
} 
kemukakan sebelumnya, maka tujuan penelitian dirumuskan sebagai berikut:

1. Menggambarkan karakteristik konsumen roti merek Sari Roti pada mahasiswa S1 Institut Pertanian Bogor.

2. Menganalisis proses keputusan pembelian konsumen roti merek Sari Roti pada mahasiswa S1 Institut Pertanian Bogor.

3. Menganalisis sikap konsumen roti merek Sari Roti pada mahasiswa S1 Institut Pertanian Bogor.

\section{TINJAUAN PUSTAKA}

\section{Atribut Bauran Pemasaran Produk Roti}

Konsumen lebih memilih produk roti tertentu atas dasar kualitas. Usia dan kualitas roti adalah penentu pembelian produk roti (Nagaraju dan Kumar, 2013). Kualitas produk makanan diidentifikasi melalui nilai, keamanan pangan, gizi dan kemasan. Komponen nilai terdiri dari komposisi bahan, ukuran, penampilan, rasa dan kenyamanan. Pilihan konsumen tergantung pada preferensi konsumen yang dipengaruhi oleh karakteristik ekstrinsik dan intrinsik. Kualitas intrinsik meliputi karakteristik fisik produk dan dapat diukur secara obyektif sedangkan kualitas ekstrinsik mewakili karakteristik produk seperti merek, distribusi, harga, kemasan dan asal mula produk (Simeone dan Marotta, 2010). Menurut Kihlberg (2004) konsumen menyukai roti karena dipengaruhi oleh kualitas sensorik roti (rasa) dan faktor non-sensorik (informasi yang diberikan dan nilai konsumen). Rasa dan label kesehatan memengaruhi per- mintaan roti (Thunstrom dan Nordstrom, 2012).

Kasus di Bangladesh, diantara atribut jenis kelamin, harga, kualitas produk, kebagusan kemasan, merek dan variasi produk, hanya tiga atribut yang memiliki pengaruh signifikan dan positif terhadap pembelian roti, yaitu jenis kelamin, merek dan kemasan (Chowdhury, 2014). Anyam et al. (2013) membuktikan bahwa harga dan atribut non-moneter yaitu label bromat, sertifikasi, label gizi, rasa dan tekstur, semuanya signifikan dalam menjelaskan pilihan konsumen. Studi Anyam et al. (2013) menunjukkan bahwa pemerintah dan produsen harus mempromosikan ketaatan label bebas bromat dan gizi, karena hasilnya menunjukkan bahwa kesediaan konsumen untuk membayar lebih tinggi dari status quo (Anyam et al. 2013).

Maric et al. (2009) menemukan bahwa urutan faktor yang memengaruhi keputusan pembelian roti adalah kualitas produk, kesegaran produk, ketersediaan produk, harga, variasi dan jenis produk, keramahan penjual, gaya hidup, kemasan, keunikan promosi dan rekomendasi dari teman. Sikap konsumen sebagai ukuran evaluasi seharusnya dapat digunakan untuk perbaikan dan pengembangan produk roti berdasarkan kualitas terbaik, yaitu kompatibel atau sesuai dengan harapan konsumen, yang mewakili elemen dasar realisasi keuntungan kompetitif dalam industri roti. Kasus di Rasina, Serbia, sebagian besar dari populasi $(81,68 \%)$ menganggap bahwa roti sangat penting pada kelompok makanan (Maric et al. 2009). 
Sejalan dengan Maric et al. (2009), menurut Tikkanen dan Vaariskoski (2010) konsumen merasa pembelian roti mereka dipengaruhi oleh bahan baku roti, rasa, cara pembuatan, karakteristik roti, penampilan produk, kualitas, asal mula produk, kemasan dan perbandingan dengan roti lainnya. Selain itu, konsumen memperoleh enam jenis manfaat dari produk roti tersebut, yaitu diklasifikasikan sebagai fungsional, emosional, kepribadian, sosial dan manfaat harga (positif negatif). Peran merek berdampak pada citra merek, yang digambarkan melalui atribut dan manfaat produk.

Skalabilitas dari metode yang diusulkan (fuzzy rule table untuk kasus produk roti) memungkinkan konsumen mengakomodasi beberapa faktor keputusan termasuk total kesehatan produk berdasarkan standar gizi individu, harga produk, persyaratan kesehatan tertentu dari konsumen dan juga kondisi sosial seperti preferensi pada makanan dan keyakinan individu (Nakandala dan Lau, 2013). Menurut Maric dan Arsovski (2010) kepuasan konsumen roti diukur melalui karakteristik atribut sebagai berikut. Kualitas pengemasan, kualitas produk, harga produk, hubungan antara harga dan kualitas, variasi dan jenis produk, ketersediaan produk, kebersihan tempat berjualan, kualitas pelayanan dan kesantunan penjual. Tinjauan literatur menunjukkan bahwa kemasan produk berpotensi memengaruhi keputusan pembelian konsumen. Elemen pada kemasan produk dapat dikategorikan menjadi dua, yaitu visual dan informasi. Elemen visual terdiri dari desain grafis, warna, penempatan gambar, ukuran dan bentuk kemasan. Sedangkan elemen informasi berhubungan dengan informasi produk dan penyajian pesan visual (Silayoi dan Speece, 2007).

Kepuasan pelanggan terhadap kualitas produk diskon didasarkan pada tiga atribut, yaitu kualitas, kinerja dan kehandalan. Persepsi kualitas terdiri dari citra merek dan iklan. Kinerja diartikan sebagai karakteristik utama pada produk dan kehandalan merupakan probabilitas kinerja produk tidak gagal ketika melewati proses produksi (Jakpar et al. 2012). Kesediaan konsumen untuk membayar roti berlabel keselamatan akan menurun ketika harga mengalami kenaikan. Sedangkan, semakin tinggi tingkat pendidikan, status perkawinan, label roti dan sumber informasi atau berita (Oviahon et al. 2011).

Skor Best-Worst menunjukkan bahwa pembelian konsumen eksklusif roti gandum secara signifikan lebih dipengaruhi oleh atribut produk yang berhubungan dengan kesehatan, sedangkan selain konsumen eksklusif roti gandum lebih dipengaruhi oleh atribut fisik produk. Penggunaan Best-Worst Scaling (BWS) adalah untuk menunjukkan peringkat kepentingan dari masingmasing atribut pada suatu produk (Cohen, 2009). Berikut urutan kepentingan atribut roti gandum berdasarkan cara pandang konsumen, terdiri dari tanggal kadaluarsa, kadar serat, kandungan gandum, harga, tingkat lemak, tingkat kalori, label gandum, ukuran kemasan, tingkat karbohidrat, label informasi gizi atau produk, merek, tingkat protein, potongan atau bentuk roti (Nguyen dan Krystallis, 2011). 
Atribut kesehatan pada produk, terkait harga dan jenis merek memiliki pengaruh terhadap loyalitas merek. Pemasar tidak harus berupaya meningkatkan kadar serat atau menurunkan harga untuk kategori roti gandum (roti sehat), tetapi lebih fokus pada label kesehatan. Sedangkan untuk kategori roti putih, dianjurkan agar mempertahankan harga rendah dan berkonsentrasi pada kadar serat tinggi, karena atribut ini diharapkan memiliki kinerja yang lebih baik berdasarkan Model Dirichlet (Nguyen dan Krystallis, 2011).

Produsen roti yang mengadopsi penggunaan tepung singkong dalam produksinya sangat memperhatikan rasa, kemasan, ukuran, warna dan harga, karena variabel-variabel ini memengaruhi keputusan membeli konsumen. Sementara kesediaan konsumen untuk membayar harga premium menunjukkan hubungan negatif dan bervariasi, tergantung pada proporsi tepung singkong (Adepoju dan Oyewole, 2013). Status sosial ekonomi konsumen tidak memengaruhi penerimaan keseluruhan roti tersubstitusi (tepung singkong dan bumbu aromatik rempah jahe), kecuali kualifikasi pendidikan. Pola konsumsi roti di Nigeria bukan dikategorikan sebagai makanan pokok dan pembelian roti dilakukan di toko-toko (Olayinka, 2010).

Shaari et al. (2013) meneliti perilaku konsumen terhadap dua pilihan roti, yaitu roti organik dibandingkan roti dengan bahan pengawet. Temuan menunjukkan bahwa secara umum roti organik akan menjadi pilihan yang lebih disukai berdasarkan urutan kepentingan rasa, kesegaran, daya tahan, halal, aspek kesehatan, tekstur, tempat dan harga sebagai penentu preferensi. Namun, tempat berperan penting dalam memengaruhi konsumen untuk membeli roti pengawet ketika konsumen merasa sulit menemukan akses untuk membeli roti organik. Di sisi lain, halal adalah faktor utama yang mengatur keputusan konsumen muslim terhadap dua alternatif tersebut. Penelitian Shaari et al. (2013) memberikan bukti tentang perilaku konsumen roti dan dapat menjadi rujukan bagi para pemasar untuk mengembangkan strategi bisnis, khususnya roti organik (Shaari et al. 2013). Sebagian besar perilaku konsumen terhadap fast moving consumer goods dipengaruhi oleh 4P (place, price, product, promotion), faktor fisiologis dan psikologis (Vibhuti et al. 2014).

Berdasarkan penelitian Poh et al. (2013) terdapat 5 faktor yang dipertimbangkan oleh masyarakat Surabaya dalam mengonsumsi produk-produk pastry dan bakery, antara lain yaitu substitusi produk sumber karbohidrat $(21,129 \%)$, gaya hidup $(13,465 \%)$, kelompok referensi $(11,290 \%)$, persepsi $(7,762 \%)$ dan sikap (6,765\%). Selain itu, hasil penelitian juga menunjukkan bahwa terdapat perbedaan perilaku masyarakat Surabaya dalam mengonsumsi produkproduk pastry dan bakery dilihat dari segi jenis kelamin, usia, pendidikan dan pekerjaan, namun tidak terdapat perbedaan perilaku dari segi pendapatan (Poh et al. 2013).

Survei Stavkova dan Turcinkova (2005) menunjukkan bahwa fakta bahwa konsumen dipengaruhi oleh pendatang baru, inovasi dan iklan saat membeli jenis 
makanan seperti permen dan biskuit, yogurt, keju, daging asap, produk daging kalengan, produk setengah jadi dan beberapa minuman (teh, anggur dan air mineral). Sedangkan konsumen yang sangat perhatian pada kesehatan mereka, membeli produk sereal roti, ikan, unggas, yogurt, keju dan air mineral. Ketika menganalisis alasan perubahan pola konsumsi, ditemukan perbedaan untuk masing-masing kelompok sosial, kategori usia individu dan lokasi yang berbeda. Apabila klasifikasi kelompok tersebut dihilangkan, alasan yang paling sering untuk mengubah pola konsumsi di semua kategori makanan adalah gaya hidup sehat. Alasan keuangan disebutkan di posisi terakhir. Kelompok usia adalah satu-satunya pengecualian, dimana ketergantungan ditunjukkan (Stavkova dan Turcinkova, 2005).

Shahnoushi et al. (2013) menunjukkan bahwa jumlah kunjungan ke toko roti per minggu, niat kunjungan ke toko roti, metode membawa roti, menunggu ketika di toko roti, penilaian harga roti dan kualitas, pendapatan bulanan rumah tangga, pendidikan rumah tangga, ratarata usia rumah tangga, rata-rata tingkat konsumsi roti, preferensi terhadap roti segar, metode pengawetan roti, pendidikan ibu, pekerjaan ibu dan jumlah anggota rumah tangga, semuanya berpengaruh pada pembelian roti oleh rumah tangga dalam jumlah lebih banyak (Shahnoushi et al. 2013).

\section{KERANGKA PEMIKIRAN}

Studi perilaku konsumen merupakan studi yang sangat menarik. Studi perilaku konsumen mencoba untuk mencari faktor-faktor penentu pembentukan perilaku. Dengan diketahuinya faktor-faktor penentu pembentukan perilaku maka perusahaan atau pemasar dapat mengendalikan perilaku konsumennya. Pengendalian disini berarti pemasar dapat menstimuli agar konsumen mau membeli produk perusahaan. Secara umum perilaku manusia merupakan hasil interaksi antara individu dan lingkungannya (Dharmestha dan Handoko, 1987). Perilaku konsumen dalam hal ini perilaku pembelian pada dasarnya juga sama dengan perilaku manusia pada umumnya, akan tetapi sebagai sebuah studi para ahli perilaku konsumen mengembangkan faktor-faktor penentu perilaku pembelian. Salah satu faktor penentu yang banyak dibahas adalah sikap (Dharmestha dan Handoko, 1987; Berkowitz, 1992; Kotler, 1997).

\section{Tahapan Keputusan Pembelian}

Schiffman dan Kanuk dalam Sumarwan (2003) mendefinisikan keputusan sebagai pemilihan suatu tindakan dari dua atau lebih alternatif pilihan. Keputusan konsumen melewati lima tahapan yaitu pengenalan kebutuhan, pencarian informasi, evaluasi alternatif, keputusan pembelian dan perilaku pasca pembelian (Kotler, 2003).

\section{Pengenalan Kebutuhan}

Pengenalan kebutuhan merupakan tahap awal dalam perilaku proses keputusan serta didefinisikan sebagai persepsi atas perbedaan antara situasi aktual yang memadai dan keadaan yang diinginkan untuk menggugah dan mengaktifkan proses keputusan. 
Pengenalan kebutuhan pada hakikatnya bergantung pada seberapa banyak ketidaksesuaian yang muncul antara keadaan aktual dan keadaan yang diinginkan. Ketika ketidaksesuaian ini melebihi tingkat atau ambang tertentu, maka kebutuhan akan dikenali.

\section{Pencarian Informasi}

Sebelum memutuskan untuk membeli, konsumen akan berusaha aktif mencari informasi sehubungan dengan kebutuhannya. Pencarian informasi merupakan tahap kedua dari proses pengambilan keputusan serta didefinisikan sebagai aktivitas termotivasi dari pengetahuan yang tersimpan di dalam ingatan atau perolehan informasi dari lingkungan. Oleh karena itu, pencarian dapat bersifat internal atau eksternal.

\section{Evaluasi Alternatif}

Setelah mengetahui berbagai merek yang tersedia di pasar, selanjutnya konsumen melakukan penilaian tentang merek-merek tersebut. Evaluasi alternatif adalah mengevaluasi berbagai alternatif dan membuat pertimbangan nilai terbaik untuk memenuhi kebutuhan. Menurut Engel et al. (1995) kriteria evaluasi bergantung pada produk. Biasanya kriteria yang digunakan adalah harga dan merek.

\section{Keputusan Pembelian}

Tahap keempat adalah keputusan pembelian. Pada tahap ini konsumen mengambil keputusan tentang apa yang dibeli, kapan membeli, dimana membeli dan bagaimana cara membayar. Keputusan pembelian pada dasarnya ada tiga kategori yaitu pembelian terencana sepenuhnya, pembelian terencana dan pembelian tidak terencana. Umumnya, pembelian suatu produk cenderung mendekatkan pada maksud membeli dan merek yang disukai.

\section{Perilaku Pasca Pembelian}

Hasil evaluasi setelah membeli dapat berupa kepuasan atau ketidakpuasan terhadap produk yang dibeli. Kepuasan dan ketidakpuasan konsumen merupakan perbandingan antara harapan konsumen sebelum pembelian dengan yang sesungguhnya diperoleh konsumen. Kepuasan akan mendorong konsumen untuk membeli dan mengonsumsi ulang produk. Sedangkan perasaan tidak puas akan menyebabkan konsumen kecewa dan menghentikan pembelian.

\section{Pengertian Sikap}

Tidak ada definisi sikap yang baku, definisi yang diberikan para ahli memiliki perbedaan satu sama lain, namun esensinya sama saja. Allport dalam Gibson (1996) mendefinisikan sikap sebagai predisposisi yang dipelajari (learned predisposition) untuk berespon terhadap suatu obyek dalam suasana menyenangkan atau tidak menyenangkan secara konsisten. Schiffman dan Kanuk (1997) memandang sikap dari segi perasaan, mereka menyatakan sikap adalah ekspresi perasaan (inner feeling) yang mencerminkan apakah seseorang senang atau tidak senang, suka atau tidak suka dan setuju atau tidak setuju terhadap 
suatu obyek. Obyek dapat berupa merek, layanan, orang, perilaku dan lain-lain. Peter dan Olson (1999) mendefinisikan sikap sebagai evaluasi konsep secara menyeluruh yang dilakukan oleh seseorang. Evaluasi adalah tanggapan pada tingkat intensitas dan gerakan yang relatif rendah. Evaluasi dapat diciptakan oleh sistem afektif maupun kognitif.

\section{METODE PENELITIAN}

Penelitian ini dilaksanakan di Kampus Institut Pertanian Bogor, Darmaga. Penentuan lokasi dipilih dengan sengaja dengan pertimbangan bahwa kebanyakan dari mahasiswa suka mengonsumsi roti merek Sari Roti di saat pagi hari atau ketika jam istirahat karena aktivitas mereka cukup padat, sehingga perlu konsumsi praktis untuk mengurangi rasa lapar dan juga banyak terdapat tokotoko yang menjual produk roti tersebut di sekitar kampus. Pelaksanaan penelitian berlangsung mulai dari Januari hingga Maret 2014.

Referensi penelitian tersebut menggunakan dua jenis data, yaitu data primer dan sekunder. Data primer diperoleh melalui wawancara dan kuesioner. Data sekunder diperoleh melalui studi kepustakaan dengan mempelajari literatur, buku, skripsi, majalah dan semua sumber yang memungkinkan dan berkaitan dengan perilaku pembelian termasuk media internet.

Penelitian menggunakan non probability sampling sebagai teknik penarikan sampel dengan metode purposive sampling. Metode tersebut dipilih karena sampel diambil berdasarkan kriteria-kriteria tertentu sesuai maksud dan tujuan, agar hasil penelitian cenderung bersifat obyektif dan memberikan informasi lebih akurat. Awalnya perlu dilakukan wawancara singkat kepada beberapa mahasiswa. Apabila salah satu dari mereka mampu mengutarakan informasi cukup banyak, maka mahasiswa tersebut berhak menjadi responden.

Populasi dari penelitian adalah mahasiswa S1 IPB meliputi delapan fakultas dan Tingkat Persiapan Bersama (TPB). Kemudian dari populasi tersebut diambil sampel mahasiswa S1 yang pernah mengonsumsi lebih dari satu kali atau bahkan pelanggan roti merek Sari Roti.

Jumlah sampel yang terlibat dalam penelitian ini adalah seratus orang. Jumlah tersebut sudah memenuhi kriteria analisis data statistik dengan ukuran sampel minimal sebanyak tiga puluh. Adapun kriteria lain yang telah dipenuhi yaitu berupa kriteria Slovin.

\section{Metode Analisis Data}

Langkah awal adalah menguji instrumen penelitian dengan persyaratan kualifikasi yang meliputi Uji Validitas dan Reliabilitas, supaya data dapat mewakili atau mencerminkan ukuran suatu keadaan. Kemudian setelah data diperoleh, dilakukan Analisis Deskriptif dan Model Sikap Multiatribut Fishbein.

Analisis Deskriptif dalam penelitian ini adalah analisis terhadap data karakteristik responden untuk memperoleh gambaran mengenai fakultas, angkatan mahasiswa, jenis kelamin, usia, sumber keuangan dan uang saku setiap bulan. Model Sikap Multiatribut Fishbein 
Tabel 1. Interval Skor dan Interpretasi Keseluruhan Sikap Responden Terhadap Roti Merek Sari Roti

\begin{tabular}{ll}
\hline Skor & Interpretasi \\
\hline $12 \quad \leq$ Ao $\leq 69,6$ & Sangat tidak suka \\
$69,61 \leq$ Ao $\leq 127,2$ & Tidak suka \\
$127,21 \leq$ Ao $\leq 184,8$ & Netral \\
$184,81 \leq$ Ao $\leq 242,4$ & Suka \\
$242,41 \leq$ Ao $\leq 300$ & Sangat suka \\
\hline
\end{tabular}

menjelaskan bahwa sikap konsumen terhadap suatu obyek sikap (produk atau merek) sangat ditentukan oleh sikap konsumen terhadap atribut-atribut yang dievaluasi. Untuk mengetahui interpretasi skor sikap tersebut, maka perlu dibuat skala interval sebagai berikut.

$$
\text { Interval }=\frac{12 \times(25-1)}{5}=57,6
$$

\section{HASIL DAN PEMBAHASAN}

\section{Karakteristik Konsumen}

Berdasarkan proporsi sample fraction, jumlah responden terbanyak adalah mahasiswa TPB. Selain mahasiswa TPB, mahasiswa angkatan 2010 juga ikut berpartisipasi dalam jumlah cukup banyak, sebagian besar perempuan, berusia sekitar 18 hingga 22 tahun dan sumber keuangan setiap bulan masih banyak yang berasal dari orang tua yang berkisar antara 500.000 rupiah sampai dengan 999.999 rupiah.

\section{Proses Pengambilan Keputusan Pembelian Roti Merek Sari Roti}

Proses pengambilan keputusan konsumen terdiri dari lima tahapan, terdiri dari pengenalan kebutuhan, pencarian informasi, evaluasi alternatif, keputusan pembelian dan perilaku pasca pembelian.
Pada tahap pengenalan kebutuhan, ketertarikan kebanyakan mahasiswa terhadap roti merek Sari Roti adalah didasari oleh motivasi keinginan untuk membeli variasi roti sesuai dengan seleranya. Namun mereka masih merasa biasa saja ketika tidak melakukan pembelian tersebut, dikarenakan seringnya berganti merek roti.

Pada tahap pencarian informasi, sebagian besar pengetahuan mahasiswa tentang roti merek Sari Roti bersumber dari iklan televisi dan cara penyampaian pesan menjadi perhatian utama. Fokus pilihan pada informasi produk roti merek Sari Roti adalah tanggal kadaluarsa.

Pada tahap evaluasi alternatif, dimana sebelum melakukan pembelian, kebanyakan dari mereka lebih cenderung mempertimbangkan harga terlebih dahulu dan merasa kemasan roti terlihat sederhana.

Pada tahap keputusan pembelian, sebagian besar variasi dan jenis roti favorit mahasiswa ada dua, yaitu roti isi krim coklat vanila dan roti sobek isi coklat. Mereka memilih variasi dan jenis roti berdasarkan selera dan pembelian dilakukan di toko atau minimarket karena dekat dengan rumah atau kos atau kampus. Peran rekomendasi dan promosi mampu membuat mereka tertarik untuk 
mencoba. Informasi produk dinilai sudah lengkap, namun pembelian masih bersifat situasional.

Pada tahap perilaku pasca pembelian, hampir keseluruhan responden menyatakan puas dan diperkuat oleh pembelian roti merek Sari Roti jenis lain jika jenis roti yang dicari belum tersedia. Apabila roti mengalami kenaikan harga, maka mereka tetap membeli roti seperti biasanya dan berniat melakukan pembelian berulang. Akan tetapi jika roti merek lain memberikan diskon atau potongan harga, konsistensi mereka tidak dapat bertahan dan beralih membeli roti merek tersebut.

\section{Sikap Konsumen terhadap Roti Merek Sari Roti}

Berdasarkan teori, salah satu faktor penentu perilaku pembelian adalah sikap. Sikap konsumen merupakan sesuatu yang penting untuk diketahui, tetapi pemasar cenderung lebih memperhatikan perilaku nyata konsumen khususnya perilaku pembelian mereka. Oleh karena itu tidak heran jika riset sikap lebih mengarah pada membangun hubungan sikap dengan perilaku. Diketahui skor sikap rata-rata terhadap roti merek Sari Roti dari seluruh jumlah responden adalah 199,83.

Berdasarkan rata-rata skor penilaian, secara keseluruhan sikap mahasiswa sebagai konsumen adalah suka roti merek Sari Roti. Teori pada umumnya menyatakan bahwa jika seseorang semakin suka terhadap suatu produk, maka semakin tinggi kemungkinan orang tersebut membeli atau menggunakan produk tersebut. Skor tersebut diperoleh dari persentase dominan pada jawaban skala kepentingan dan kepuasan untuk mengukur sikap.

Berdasarkan hasil uji validitas dan reliabilitas, atribut produk terdiri dari harga, variasi jenis, kualitas bahan baku, kemudahan mendapatkan, informasi produk, label halal, tekstur produk, rasa, merek, kejelasan kadaluarsa, warna produk dan aroma.

Atribut kejelasan kadaluarsa memperoleh penilaian kepentingan paling

\section{Tabel 2. Perhitungan Skor Sikap Multiatribut Fishbein}

\begin{tabular}{lccc}
\hline Atribut & $\mathbf{e}_{\mathbf{i}}$ & $\mathbf{b}_{\mathbf{i}}$ & $\mathbf{b}_{\mathbf{i} \cdot \mathbf{e}_{\mathbf{i}}}$ \\
\hline Kejelasan kadaluarsa & 4,30 & 4,63 & 19,90 \\
Label halal & 4,30 & 4,62 & 19,86 \\
Rasa & 4,24 & 4,51 & 19,12 \\
Kualitas bahan baku & 3,95 & 4,37 & 17,26 \\
Harga & 3,26 & 4,36 & 14,21 \\
Variasi dan jenis & 4,05 & 4,32 & 17,49 \\
Tekstur produk & 3,91 & 4,21 & 16,46 \\
Kemudahan mendapatkan & 3,95 & 4,20 & 16,59 \\
Informasi produk & 3,79 & 3,98 & 15,08 \\
Aroma & 3,89 & 3,91 & 15,20 \\
Warna produk & 3,82 & 3,85 & 14,70 \\
Merek & 3,74 & 3,72 & 13,91 \\
\hline \multicolumn{2}{l}{} & & 199,83 \\
\hline
\end{tabular}


tinggi di dalam persepsi konsumen (Tabel 2). Apabila sikap konsumen terhadap roti merek Sari Roti diinterpretasikan, maka mereka berkeyakinan bahwa kejelasan kadaluarsa pada kemasan tertera sangat jelas. Artinya, kepentingan atribut tersebut berada di posisi paling baik dibandingkan kepentingan atribut lainnya. Sedangkan merek atau brand Sari Roti sangat dianggap tidak penting dalam penilaian konsumen.

Atribut label halal dan kejelasan kadaluarsa memperoleh penilaian evaluasi paling tinggi dalam mempengaruhi kepuasan konsumen setelah membeli roti merek Sari Roti. Keduanya memperoleh rata-rata skor yang sama (Tabel 2). Mahasiswa S1 IPB menganggap bahwa kinerja atribut label halal dan kejelasan kadaluarsa sudah mampu membuat mereka merasa puas. Selain itu, pada awalnya mereka juga menaruh harapan tinggi pada kejelasan kadaluarsa dan alhasil keyakinan tersebut dapat diterima sepenuhnya. Hal ini dibuktikan dengan posisi hasil dari rata-rata Kepercayaan dan Evaluasi berada di urutan pertama. Adanya label halal dari Majelis Ulama Indonesia mampu memberikan tingkat kepuasan yang sama dengan keberadaan tanggal kadaluarsa.

\section{Implikasi Manajerial}

Hasil penelitian membuktikan bahwa sikap konsumen mahasiswa S1 IPB terhadap roti merek Sari Roti adalah suka. Sikap merupakan ungkapan perasaan konsumen ketika menyukai suatu obyek atau dapat merupakan kepercayaan konsumen terhadap berbagai manfaat dari suatu produk. Semakin suka sikap seseorang, maka semakin tinggi kemungkinannya untuk membeli atau menggunakan produk tersebut. Bagi Perseroan, sikap positif konsumen akan berdampak pada peningkatan efektivitas iklan dan penurunan biaya kegagalan pemasaran.

Kesamaan posisi skor Kepercayaan dan Evaluasi pada atribut kejelasan kadaluarsa di urutan dua teratas mengindikasikan bahwa penting bagi Perseroan dan distributor untuk memerhatikan dan memeriksa kembali tanggal kadaluarsa sebelum produk dijual ke konsumen akhir, agar konsumen tidak merasa kecewa dan Perseroan dapat mempertahankan sikap positif mereka terhadap roti merek Sari Roti.

\section{SIMPULAN DAN SARAN}

\section{Simpulan}

Sebagian besar responden yang mengonsumsi roti merek Sari Roti adalah perempuan, berusia sekitar 18 hingga 22 tahun dan sumber keuangan setiap bulan masih banyak yang berasal dari orang tua yang besarannya dibawah satu juta rupiah.

Konsumen melalui seluruh tahapan proses pengambilan keputusan pembelian roti merek Sari Roti. Pertama, ketertarikan konsumen terhadap roti merek Sari Roti adalah didasari oleh motivasi keinginan untuk membeli variasi roti sesuai dengan seleranya. Kedua, pengetahuan konsumen tentang roti merek Sari Roti bersumber dari iklan televisi dan cara penyampaian pesan menjadi perhatian utama. Ketiga, sebelum membeli mereka lebih cenderung mempertimbangkan harga terlebih dahulu dan merasa kemasan roti terlihat sederhana. 
Keempat, variasi dan jenis roti favorit konsumen ada dua, yaitu roti isi krim coklat vanila dan roti sobek isi coklat. Pembelian dilakukan di toko atau minimarket karena dekat dengan rumah atau kos atau kampus. Peran promosi mampu membuat mereka tertarik untuk mencoba. Informasi produk dinilai sudah lengkap, namun pembelian masih bersifat situasional. Kelima, setelah membeli, perasaan puas mendominasi dan diperkuat oleh pembelian roti merek Sari Roti jenis lain jika jenis roti yang dicari belum tersedia.

Hasil penelitian membuktikan bahwa sikap konsumen mahasiswa S1 IPB terhadap roti merek Sari Roti adalah suka. Namun atribut dengan skor penilaian evaluasi terendah adalah harga.

\section{Saran}

Berdasarkan hasil penelitian, konsumen memberikan skor evaluasi terendah pada atribut harga. Mereka bersikap suka terhadap roti merek Sari Roti, namun atribut harga akan menentukan seberapa banyak pembelian yang dilakukan. Penentuan harga harus dilakukan secara hati-hati agar Perseroan dapat mempertahankan pangsa pasarnya.

Rekomendasi bagi penelitian selanjutnya adalah menambahkan variabel emosional dan situasional, membandingkan keputusan pembelian antara mahasiswa dan non mahasiswa (umum) serta membandingkan keputusan pembelian roti merek Sari Roti dan merek lain.

\section{DAFTAR PUSTAKA}

Adepoju, Abimbola O dan Olaniyi O Oyewole. 2013. Households' perception and willingness to pay for bread with cassava flour inclusion in Osogbo Metropolis, Osun State, Nigeria. The 4th international conference of the african association of agricultural economists.

Anyam, Osemeke E, Ayodele E Fashogbon dan Omobowale A Oni. 2013. Consumers' willingness to pay for safety attributes of bread in Lagos Metropolis, Nigeria. The 4th international conference of the african association of agricultural economists.

Berkowitz, Kerin dan Rudelius. 1992. Marketing. Boston: Richard D Irwin Inc.

Charles S. 2013. Globalisasi dan pola makan mahasiswa: studi kasus di Jakarta. CDK-205, 40 (6): 1-6.

Chowdhury, Masum. 2014. Factors influencing consumer buying pattern towards bread item in Bangladesh study on "All time" brand under pran group. [Project report]. Departemen Administrasi Bisnis. East West University, Dhaka.

Cohen, Eli. 2009. Applying the bestworst scaling to wine marketing. International journal of wine business research, 2 (1): 8-23.

Dharmmesta dan Handoko. 1987. Manajemen Pemasaran: Analisa Perilaku Konsumen. Yogyakarta: Liberty. 
Engel, James F, Roger D Blackwell dan Paul F. Minard. 1995. Consumer Behaviour. Edisi 8. New York: The Dryden Press.

Gibson. 1996. Organisasi dan Manajemen. Jakarta: Erlangga.

Jakpar, Shaharudin, Angelyn Goh Sze $\mathrm{Na}$, Anita Johari dan Khin Than Myint. 2012. Examining the product quality attributes that influences customer satisfaction most when the price was discounted: a case study in Kuching Sarawak. International Journal of Business and Social Science, 3 (23): 221-236.

Kihlberg, Iwona. 2004. Sensory quality and consumer perception of wheat bread towards sustainable production and consumption, effects of farming system, year, technology, information and values [Disertasi]. Program Doktor Ilmu Sosial. Universitas Uppsala, Swedia.

Kotler. 1997. Manajemen Pemasaran: Analisis, Perencanaan, Implementasi dan Kontrol. Jilid 1. Edisi Bahasa Indonesia. Jakarta: Prenhallindo.

Kotler. 2003. Marketing Management An Asian Perspective. Edisi 3. Singapore: Prentice Hall Pearson Education Asia Pte. Ltd.

Maric, Aleksandar, Slavko Arsovski dan Jasna Mastilovic. 2009. Contribution to the improvement of products quality in baking industry. International journal for quality research, 3 (3).
Maric, Aleksandar dan Slavko Arsovski. 2010. The level of customer satisfaction as one of the goals of the quality of the organization in the bakery industry. International journal for quality research, 4 (4): 275-281.

Nagaraju dan Girish Kumar. 2013. Consumer behaviour of fast moving consumer goods - a study on bakery products. Innovative Thoughts International Research Journal, 1 (3).

Nakandala, Dilupa dan Henry C W Lau. 2013. An application of a fuzzybased optimisation model for selecting food products based on cost and nutrition. Journal of research for consumers, 24.

Nguyen, Louise Tu-Nga dan Athanasios Krystallis. 2011. The influence of health-related product attributes, consumers' psychographic characteristics and consumers' health eating discourses on food categories with a healthy profile: the case of branded bread [Tesis]. Master of Science in Marketing. Department of Marketing and Statistics. Aarhus School of Business. Aarhus University, Denmark.

Olayinka, Akinpelu Righteous. 2010. Consumer acceptability of spiced composite bread [Skripsi]. Departemen Ilmu dan Teknologi Pangan. Universitas Pertanian Abeokuta, Nigeria. 
Oviahon, S A Yusuf, R J Akinlade dan O L Balogun. 2011. Determinants of bread consumers' willingness to pay for safety labels in Oredo Local Government Area, Edo State, Nigeria. New York science journal, 4 (9): 15-20.

Peter dan Jerry C Olson. 1999. Perilaku Konsumen dan Strategi Pemasaran. Edisi 4. Jakarta: Erlangga.

Poh, Sylvia Indrayana, Budi Hendrawan, Sienny Thio. 2013. Perilaku konsumsi dan faktor-faktor yang mempengaruhi masyarakat Surabaya dalam mengkonsumsi produk-produk pastry dan bakery. Student journal of Petra Christian University.

Schiffman dan Leslie Lazar Kanuk. 1997. Perilaku Konsumen. Edisi 5. New Jersey: Prentice Hall Inc.

Shaari, Jamal Abdul Nassir Shaari, Haslan Ottot dan Muhammad Farhan Kermin. 2013. Halal; organic; and preservative: marketing concept for bread industry. Proceedings of annual Paris business and social science research conference.

Shahnoushi N, Saghaian S, Reed M, Firoozzare A dan Jalerajabi M. 2013. Investigation of factors affecting consumers' bread wastage. Journal of agricultural economics and development, 2 (6): 246-254.

Silayoi, Pinya dan Mark Speece. 2007. The importance of packaging attributes: a conjoint analysis approach. European journal of marketing, 41 (11/12): 1495-1517.
Simeone, Mariarosaria dan Giuseppe Marotta. 2010. Towards an integration of sensory research and marketing in new food products development: a theoretical and methodological review. African journal of business management, 4 (19): 4207-4216.

Siti W. 2006. Analisis komparasi konsumsi pangan mahasiswa universitas muhammadiyah malang sebelum dan sesudah kenaikan bahan bakar minyak (BBM) (studi kasus pada mahasiswa Jurusan Agribisnis UMM) [Skripsi]. Departemen Agribisnis. Universitas Muhammadiyah Malang, Malang.

Stavkova, J dan J Turcinkova. 2005. Consumer choice process when purchasing the staple food. Czech academy of agricultural sciences, 51 (9): 389-394.

Sugiyono. 2011. Metode Penelitian Kuantitatif, Kualitatif dan $R \& D$. Bandung: Alfabeta.

Sumarwan. 2003. Perilaku Konsumen: Teori dan Penerapannya dalam Pemasaran. Bogor: Ghalia Indonesia.

Sumarwan. 2011. Perilaku Konsumen: Teori dan Penerapannya dalam Pemasaran. Edisi 2. Bogor: Ghalia Indonesia.

Thunstrom, Linda dan Jonas Nordstrom. 2012. The importance of taste for food demand and the experienced taste effect of healthy labels. Swedish retail and wholesale development council funds research. 
Tikkanen, Irma dan Mari Vaariskoski. 2010. Attributes and benefits of branded bread: case Artesaani. British food journal, 112 (9): 10331043.

Vibhuti, Ajay Kumar Tyagi, Vivek Pandey. 2014. A case study on consumer buying behavior towards selected FMCG products. International journal of scientific research and management, 2 (8): 1168-1182. 